\title{
Ethnic Militancy in Nigeria: A Comparative Re-appraisal of three Major Ethnic Militias in Southern Nigeria
}

\author{
Lysias Dodd Gilbert, $\mathrm{PhD}$ \\ (Department of Political Science, Ignatius Ajuru University of Education, Port Harcourt, Nigeria)
}

\begin{abstract}
Since the commencement of the $4^{\text {th }}$ Republic in Nigeria in May 1999, one relatively permanent characterisation of the country's political landscape has been ethnic militancy. Ethnic militancy exacerbated insecurity; confronted the status of the state as the sole legitimate monopolist of the instruments of force and violence; exposed the weak loyalty and allegiance of the populace to the Nigerian nation-state project; and threatened its continued existence as a corporate entity. Decades of marginalisation and injustice foisted on the citizenry by the Nigerian state, precipitated a spectre of frustration and deprivation, which triggered the formation of militant groups as extra-constitutional method for negotiation, and redressing the political cum socio-economic dehumanising conditions of the people. Prominent among such groups in southern Nigeria are: Oodua People's Congress (OPC), the Movement for the Actualisation of the Sovereign State of Biafra (MASSOB) and the Movement for the Emancipation of the Niger Delta (MEND). This comparative study based on field research and data from secondary sources, revisits and re-examines the origins and dynamics of these three militia groups. Using the elite-instrumentalist theoretical perspective, the paper argues that among the three ethnic militia groups studied, only OPC was specifically formed and deployed by some Yoruba political elite as an instrument for the actualisation of their political objectives. Furthermore, it recommends the convocation of a Sovereign National Conference or an inclusive national conference whose decisions shall be subjected to a properly conducted referendum as a fundamental panacea to the challenge of ethnic militancy in Nigeria.
\end{abstract}

Keywords: Comparative, Elite-instrumentalist, Ethnic Militancy, Reappraisal, Southern Nigeria

\section{Introduction}

Gilbert (2010: 164) defined ethnic militia "...as any non-state belligerent (actor) systematically fighting on the premise of ethno-nationalism (in any part of Nigeria) for the purpose of defending and projecting the interests of an ethnic nationality." The basic factor that distinguishes an ethnic militia from other forms of armed groups like cults and religious fundamentalists is that they zealously defend and project the interests of their respective ethnic nationalities, by any means, including the use of arms. Therefore, ethnic militancy is a situation whereby non-state belligerents are engaged in the act of defending and projecting the supposed interests of their ethnicities, by any possible measure, not excluding the use of arms.

The Tiv riots in the Northern region (North Central geo-political zone) marked the beginning of ethnic militancy in post-colonial Nigeria. Subsequently, there were the Agbekoya (farmers) revolt in the Western region (South West geo-political zone), the Isaac Adaka Boro-led '12 Day revolution' (South-South geopolitical zone) and the Biafran secessionist war in the Eastern region (South East geo-political zone). Nevertheless, the economic prosperity of the 1970s; the painful occurrence of the civil war - 1967-1970 and the fear of the military government, combined to discourage the emergence of ethnic militancy in the post-civil war era (Gilbert, 2010).

However, decades of authoritarianism, marginalisation, injustice and bad governance foisted on the citizenry by the Nigerian state (represented by successive military regimes), precipitated a spectre of frustration and deprivation, which triggered the formation of militant ethnic groups as extra-constitutional method for negotiation and redressing the political cum socio-economic dehumanising conditions of the people. In addition, was the failure of the newly enthroned civilian administration to meet the expectations of the Nigerian populace after several years of military dictatorship. Some of the militia groups formed were, the Movement for the Actualization of the Sovereign State of Biafra (MASSOB), the Arewa People's Congress (APC) and Oodua

People's Congress, which emerged from the three major ethnic groups of Igbo, Hausa/Fulani and Yoruba respectively. Similarly, several other groups including Movement for the Survival of Ogoni People (MOSOP), Ijaw Youth Congress (IYC), the Federated Niger Delta Ijaw Communities (FNDIC), Egbesu Boys of Africa (EBA), Niger Delta Peoples Volunteer Force (NDPVF), Niger Delta Strike Force (NDSF) and the Movement for the Emancipation of the Niger Delta (MEND) proliferated in the Niger Delta.

Furthermore, it has been argued that ethnic militancy emerged in the country due to the perceived marginalisation of some ethnic groups by the Nigerian state (Anifowose, 2000; Akinboye, 2001; Akinyele, 
2001; Babawale, 2001). In this context, OPC was formed specifically to fight against the political marginalisation of the Yoruba ethnic nationality; MASSOB was established for the struggle against Igbo marginalisation since the end of the civil war; FNDIC, EBA, NDPVF and MEND were also formed to struggle against the political, socio-economic and environmental marginalisation of the Ijaw ethnic group and by extension, the Niger Delta region.

Jinadu (1985: 72-73) contends that one major characterisation (and problem synonymous with) of heterogeneous societies is the fact that the state is not usually "a neutral force in mediating political conflict", because "it can be captured and used to further the interests of the leadership of an ethnic group or combination of such groups." Awodiya (2006: 2) concurs by positing that ethnic militia groups were concentrated in the southern part of Nigeria because successive, highly centralised military regimes used political power for the lopsided authoritative allocation of resources between 1966 and 1979 and between 1984 and 1999 in the interest of the hegemonic Hausa/Fulani ethno-national group or simply the political North. The obvious implication therefore is that the political elite in the various ethnic nationalities in the south resorted to the encouragement and sponsorship of the formation of various ethnic militia groups for the advancement of their collective group interests. It is against this backdrop that this paper re-appraises the origins and dynamics of three ethnic militias in the southern part of Nigeria; namely, OPC, MASSOB and MEND. The justification for their selection is that, $\mathrm{OPC}$ is the only ethnic militia in the Yoruba ethnic nationality and it was also, the first ethnic militia formed in the 1990s in Nigeria. Similarly, MASSOB is the only ethnic militia in the Igbo ethnic group, while MEND is the most prominent and tenacious pan-Ijaw ethnic militia with considerable impact in the prosecution of belligerent ethno-nationalism in the Niger Delta region.

Developed from a doctoral thesis submitted to the University of KwaZulu-Natal in South Africa on ethnic militias and conflict in the Niger Delta of Nigeria, this study is based on primary sources gathered during field trips to the Delta region, including focus group discussions, interviews with current and former militants/armed gang members, security agencies, government officials, major civil society leaders, Nigerian National Petroleum Corporation (NNPC) staff, MNOC staff, traditional rulers, eminent journalists, Community Based Organization (CBO) leaders/members, academics, and some ordinary people of the Delta region, as well as secondary sources. With the use of the elite-instrumentalist theoretical perspective, the paper argues that among the three ethnic militia groups studied, only OPC was specifically formed and deployed by some Yoruba political elite as an instrument for the actualisation of their political objectives. The other two major militant groups in southern Nigeria, MASSOB and MEND were not formed in the context of the elite-instrumentalist perspective of ethno-nationalist rationalisation. Furthermore, it recommends the convocation of a Sovereign National Conference or an inclusive national conference whose decisions shall be subjected to a properly conducted referendum as a fundamental solution to the challenge of ethnic militancy in Nigeria.

\section{Theoretical Explications}

The elite-instrumentalist perspective on ethnicity (Otite, 1975; Enloe 1980; Horowitz, 1985; Diamond 1988; Osaghae, 1991; Osaghae, 1995; Auster 1996) is the theoretical framework on which this research work is predicated. The instrumental theory argues that ethnic identity is "created and constructed by the ethnic elite" (Eriten \& Romine, n.d: 2). According to Pareto (1968: 8) elites are members of any community "who score highest on scales measuring any social value or commodity (utility) such as power, riches, knowledge". Though they usually constitute a 'privileged minority' from all sectors, elites occupy prominent and important positions in any given society and "play critical roles in ethnic mobilisation" (Osaghae, 1991: 46-47). The notion is that since the acquisition of political power is a sine qua non for access to socio-economic resources for the enhancement and reproduction of elites in most developing countries, elites resort to the politicisation and mobilisation of their ethnic groups for the 'capturing' of state power; especially whenever such prospects could easily be obstructed.

Besides, this conception posits that established elites and emerging or hopeful elites as a result of their relative organisational advantage use ethnicity as a mechanism for the mobilisation of ordinary members of their ethnic group for the actualisation of their personal/group interests. More often than not, it is argued that personal interests of members of the elite are camouflaged as group interests. Ethnicity is thus a major instrument in inter-elite competition for winning and retaining political power and accessing and exploiting other socio-economic resources largely, but not solely, in favour of the elites. Eriten \& Romine (n.d: 4) contend that "ethnicity is propagated and manipulated by elites, or proto-elites, aiming at either material advantages or power, or both". On the specific Nigerian case, noting that the various "ethnic grievances and demands" are clearly "elite-begotten interests", Osaghae argues that ethnicity "is epiphenomenal, as its existence is a function of the manipulations of the masses by the elite or privileged class" (2001: 4-5; 1991: 47). Similarly, Young (1994: 77) is of the view that instrumentalism draws our attention to the "contingent, situational and circumstantial" deployment of ethnicity "in the pursuit of material advantage." 
Further, Ake (1996) posits that socio-economic insecurity is one of the reasons that accounts for the identification of people with their respective ethnic groups. Therefore, their impoverished socio-economic situation coupled with their poor level of enlightenment, renders them vulnerable for easy mobilisation by ethnic entrepreneurs (Kaur, 2007; Metumara, 2010). Second is the problem of unequal development, opportunities and prospects for advancement available to different ethnic groups in a particular geopolitical system (Osaghae, 1991). Even if such ethnicisation started off peacefully, there is always the possibility that it could turn violent if the objectives and goals of the ethnic entrepreneurs are not easily realised. It is in this context that Nnoli (1993: 6-8) observed that "under conditions of intense socio-economic competition in the society, ethnicity is associated with hostility, conflict and violence".

In the southern part of Nigeria, the high level of dissatisfaction and irritation with the repressive political and economic policies of the Nigerian state triggered the emergence of various ethno-national groups with the purported aim to protect and project the interests of their respective nationalities. People literally migrated from the non-consensual pan-Nigerian idea to their respective ethno-nationalist platforms, which some members of the political elite, used as strategic avenues of mobilisation and solidarity against perceived marginalisation and as a source of support against the politico-economic onslaught engineered by the Nigerian state. This was similar to the decisive shift of people from the pan-Nigerian nationalist fervour after independence to their respective ethno-regional bases, which were strategically deployed as instruments of struggle for resource acquisition and control in the country (Coleman, 1971; Ukeje \& Adebanwi, 2008). A situation where only the North (Hausa/Fulani) hegemonically controlled the authoritative allocation of resources due to its unbridled access to the presidency either through flawed elections or coup d'états was seriously brought into question for the first time. In his analysis, Orji (2008: 135) explained that between 1960 and 2007, the North had ruled the country in executive capacity for 412 months totalling $73.4 \%$ of the period, while the South had governed for 148 months representing $26.1 \%$ of the duration. Clearly, there was ample evidence to justify the agitations of the southern minorities against political marginalisation in Nigeria.

For example, as shown in Table 1 below, between 1960 and 2013, Northern Nigeria had controlled central political power (in executive capacity) for more than thirty seven years; while southern leaders have only governed for fifteen years and some months. However, as at 1999, southern political elite only had access to the presidency temporarily and by default. Groups such as MOSOP, Ethnic Minority Rights Association of Africa (EMIROAF), EBA, and OPC, therefore, emerged in the early and mid 1990s as platforms for resurgent ethnic identity politics. And "defiance to the oligarchic Hausa/Fulani-controlled Nigerian state ... became the norm" (Gilbert, 2010: 18). Against this backdrop therefore, the paper uses the elite-instrumentalist perspective on ethnicity as the explanatory model for the re-appraisal of ethnic militancy in Nigeria.

Table 1: Heads of State, their Ethnic Groups and Geopolitical Zones in Nigeria (1960 - 2010)

\begin{tabular}{|c|c|c|c|c|c|}
\hline Date & $\begin{array}{l}\text { Type of } \\
\text { Government }\end{array}$ & $\begin{array}{l}\text { Head of } \\
\text { State/Government }\end{array}$ & Ethnic Group & $\begin{array}{l}\text { Geo-political } \\
\text { Zone }\end{array}$ & Duration \\
\hline $\begin{array}{l}01 \text { October } 1960- \\
15 \text { January } 1966\end{array}$ & Civilian & $\begin{array}{l}\text { Dr. Nnamdi Azikiwe } \\
\text { (Governor- } \\
\text { General/President) }\end{array}$ & Ibo & $\begin{array}{l}\text { South (South- } \\
\text { East) }\end{array}$ & $\begin{array}{l}5 \text { years and } \\
31 / 2 \text { months }\end{array}$ \\
\hline $\begin{array}{l}01 \text { October } 1960- \\
15 \text { January } 1966\end{array}$ & Civilian & $\begin{array}{l}\text { Alh. Tafawa Balewa } \\
\text { (Prime Minster) }\end{array}$ & Hausa/Fulani & $\begin{array}{l}\text { North (North- } \\
\text { East) }\end{array}$ & $\begin{array}{l}5 \text { years and } \\
31 / 2 \text { months }\end{array}$ \\
\hline $\begin{array}{l}\text { 15 January } 1966- \\
29 \text { July } 1966\end{array}$ & Military & Gen. Aguiyi Ironsi & Ibo & $\begin{array}{l}\text { South (South- } \\
\text { East) }\end{array}$ & $61 / 2$ months \\
\hline $\begin{array}{l}\text { 29 July } 1966-29 \\
\text { July } 1975\end{array}$ & Military & Gen.Yakubu Gowon & Angas & $\begin{array}{l}\text { North (North- } \\
\text { Central) }\end{array}$ & 9 years \\
\hline $\begin{array}{l}29 \text { July } 1975- \\
\text { February } 1976\end{array}$ & Military & $\begin{array}{l}\text { Gen. Murtala } \\
\text { Mohammed }\end{array}$ & Hausa/Fulani & $\begin{array}{l}\text { North (North- } \\
\text { West) }\end{array}$ & 6 months \\
\hline $\begin{array}{l}13 \text { February } 1976- \\
01 \text { October } 1979\end{array}$ & Military & $\begin{array}{l}\text { Gen. Olusegun } \\
\text { Obasanjo }\end{array}$ & Yoruba & $\begin{array}{l}\text { South (South- } \\
\text { West) }\end{array}$ & $\begin{array}{l}3 \text { years, } 2 \text { wks } \\
\text { and } 3 \text { days }\end{array}$ \\
\hline $\begin{array}{l}01 \text { October } 1979- \\
31 \text { December } 1983\end{array}$ & Civilian & Alh. Shehu Shagari & Hausa/Fulani & $\begin{array}{l}\text { North (North- } \\
\text { West) }\end{array}$ & $\begin{array}{l}4 \text { years and } \\
3 \text { months }\end{array}$ \\
\hline $\begin{array}{l}31 \text { December } 1983 \\
-27 \text { August } 1985\end{array}$ & Military & $\begin{array}{l}\text { Gen. Mohammadu } \\
\text { Buhari }\end{array}$ & Hausa/Fulani & $\begin{array}{l}\text { North (North- } \\
\text { West) }\end{array}$ & $\begin{array}{l}1 \text { year and } \\
8 \text { months }\end{array}$ \\
\hline $\begin{array}{l}\text { 27August } 1985- \\
26 \text { August } 1993\end{array}$ & Military & $\begin{array}{l}\text { Gen. Ibrahim } \\
\text { Babangida }\end{array}$ & $\begin{array}{l}\text { Nupe } \\
\text { (Hausa/Fulani) }\end{array}$ & $\begin{array}{l}\text { North (North- } \\
\text { Central) }\end{array}$ & 8 years \\
\hline $\begin{array}{l}26 \text { August } 1993- \\
17 \text { November } 1993\end{array}$ & Civilian & $\begin{array}{l}\text { Chief Earnest } \\
\text { Shonekan }\end{array}$ & Yoruba & $\begin{array}{l}\text { South (South- } \\
\text { West) }\end{array}$ & $\begin{array}{l}2 \text { months and } 3 \\
\text { weeks }\end{array}$ \\
\hline $\begin{array}{l}17 \text { November } 1993 \\
-08 \text { June } 1998\end{array}$ & Military & Gen. Sani Abacha & Kanuri & $\begin{array}{l}\text { North (North- } \\
\text { East) }\end{array}$ & $\begin{array}{l}4 \text { years and } \\
6 \text { months and } 3 \\
\text { weeks }\end{array}$ \\
\hline $\begin{array}{l}\text { 09 June } 1998-29 \\
\text { May } 1999\end{array}$ & Military & $\begin{array}{l}\text { Gen. Abdulsalam } \\
\text { Abubakar }\end{array}$ & $\begin{array}{l}\text { Nupe } \\
\text { (Hausa/Fulani) }\end{array}$ & $\begin{array}{l}\text { North (North- } \\
\text { Central) }\end{array}$ & $\begin{array}{l}11 \text { months and } 3 \\
\text { weeks }\end{array}$ \\
\hline $\begin{array}{l}29 \text { May } 1999-29 \\
\text { May } 2007\end{array}$ & Civilian & $\begin{array}{l}\text { Chief Olusegun } \\
\text { Obasanjo }\end{array}$ & Yoruba & $\begin{array}{l}\text { South (South- } \\
\text { West) }\end{array}$ & 8 years \\
\hline
\end{tabular}




\begin{tabular}{|l|l|l|l|l|l|}
\hline $\begin{array}{l}\text { 29 May 2007-05 } \\
\text { May 2010 }\end{array}$ & Civilian & $\begin{array}{l}\text { Alhaji Umaru Musa } \\
\text { Yar'Adua }\end{array}$ & Hausa/Fulani & $\begin{array}{l}\text { North (North- } \\
\text { West) }\end{array}$ & $\begin{array}{l}3 \text { years and 3 } \\
\text { weeks and 4 days }\end{array}$ \\
\hline 06 May 2010 - Date & Civilian & Dr. Jonathan Goodluck & Ijaw & $\begin{array}{l}\text { South (South- } \\
\text { South }\end{array}$ & \\
\hline
\end{tabular}

Source: Gilbert, 2010: 148

\section{A Comparative Re-appraisal of three Major Ethnic Militias in Southern Nigeria: OPC, MASSOB and MEND}

\subsection{The Oodua People's Congress (OPC)}

The OPC was formed by a Yoruba medical practitioner and politician, Dr. Fredrick Fasheun on 24 August 1994 (Akinyele, 2001: 625). Its formation was triggered by the cruel annulment of the now famous June 12 (1993) presidential election, widely believed to have been won by a Yoruba business mogul, Chief M.K.O Abiola by the Babangida's military regime. The annulment elicited massive violent protests nation-wide. For the majority of the Yoruba socio-political and cultural elite, the annulment of the June 12 election was adjudged as a serious affront against the Yoruba people. Secondly, the open support given to the dastardly act by prominent Hausa/Fulani personalities, including the serving Sultan of Sokoto at the time, Alhaji Ibrahim Dasuki, was indicative of the fact that the Hausa/Fulani political elite, amongst others, did not want political power to be handed over to a Yoruba person in Nigeria. Therefore, the invalidation of the election on flimsy grounds was considered an insult to the totality of the Yoruba ethnic nationality, who felt the Hausa/Fulani considered them as second-class citizens unqualified to mount the presidential saddle in a democratic Nigeria (Ukeje \& Adebanwi, 2008). Confirming this notion, Fasheun (2002: 262) stated that:

For a good part of four decades, the Yoruba were unjustly prevented from mounting the leadership throne of [Nigeria]. The frustration lingered from the late ... Awolowo ... to ... Abiola. Awo died. But the curse passed on to Abiola, another Yoruba man, the richest of his race, who had shared various facts of life _ money, business, property, religion, even women - with the Caliphate (the north) ... But instead of allowing him the dividend of his victory, the military (induced by the Caliphate) cancelled the election and annulled his victory. Finally, he was incarcerated and killed by poisoning.

The consequent onslaught on democracy and anti-annulment activists by both the Babangida and Abacha dictatorships, and the incarceration of Abiola in June 1994, prompted Fasheun who hitherto was also a human rights activist, to resort to the mobilisation of youths for the purpose of ethnic militancy. This was in defence of the Yoruba ethnic nationality, actualisation of Abiola's mandate, opposition of the political marginalisation of the Yoruba and fighting for self-determination for the Yoruba ethnic nationality (Akinyele, 2001: 625-626; Sesay, etal, 2003).

Fasheun conceded that he personally mobilised the youths to fight against the marginalisation of the Yoruba, thereby giving credence to the elite-instrumentalist perspective of ethnicity. There was therefore, no pretension about the status of OPC as a socio-cultural organisation. It's membership was not globalised but localised to the Yoruba ethnic nationality and its inter-ethnic violence against the Hausa/Fulani, Igbo and Ijaw was in consonance with its ethno-nationalistic irredentism, which was clearly expressed in its objectives. It emotionally protected the interests of the Yorubas as members of its socio-cultural community, "while preying upon people outside their definition of a community" (Reno, 2006: 27).

To give wider legitimacy, support, approval and acceptance to OPC by most Yoruba people, it was constructed on the premise of the primordial collective identity of Oduduwa, the mythical progenitor of the Yoruba nation. Its symbol was the image of Oduduwa, its anthem and motto were also based on the ancestry of Oduduwa to the Yoruba ethnic group (Akinyele, ibid). Closely related to the foregoing is the framing of OPC in the "Awolowo's pro-poor, pro-Yoruba ideological legacy" (Guichaoua, 2006: 15). These factors ensured speedy popularity and support for the organisation both at the grassroots and amongst the elites. And it was widely supported by renowned Yoruba nationalists such as the late Chief Michael Adekunle Ajasin (the revered leader of Afenifere and NADECO); late Dr. Beko Ransome-Kuti (a notable human rights activist and Chairman of Campaign for Democracy); and late Chief Bola Ige (former governor of Old Oyo State, prominent Afenifere leader, and former Attorney General of the Federation during President Obasanjo's first term, 19992003)_(Guichaoua, 2006: 10-11). In addition, OPC advocated for the convocation of a Sovereign National Conference (SNC) of all ethnic nationalities for the restructuring of Nigeria, the review of the derivation principle of revenue allocation in favour of the producing states and the practice of true federalism in the country.

Worthy of note is the fact that OPC did not commence its militant posture until after the arrest and detention of its leader by the Abacha junta in December 1996. This incident made the OPC members feel that Nigerian problems could not be resolved peacefully. Perhaps, it was OPC's violent ethno-nationalistic endeavours that 'popularised' it nation-wide as an ethnic militia more than anything else. Second was the split of the organisation into two factions led separately by Fasheun and Gani Adams. The split was not so much about the objectives of the organisation as about how to realise them (more as a result of the controversy on how 
to prosecute the ethno-nationalistic fight for the realisation of the set objectives of the group). The emergence of Obasanjo as the first president of the $4^{\text {th }}$ Republic seemed to have precipitated this scenario. While the youthful Adams faction rooted for the continuation of militancy as the most viable tool for the realisation of Yoruba selfdetermination, the older Fasheun faction called for a thaw and support for the Obasanjo presidency. It is on record that much of the violence was unleashed by the more idealistic Adam's faction (Akinyele, 2001; Sesay, etal, 2003; Ukeje \& Adebanwi, 2008).

The militant ethno-nationalism of OPC instilled fear and insecurity in some northern elites who felt that the Obasanjo government was not firm enough in taming OPC and that his administration was marginalising the north. Therefore they decided on the formation of a counter group on 13 December 1999 to checkmate the activities of OPC and also fight against the perceived marginalisation of the north. Sagir Mohammed, a retired military officer became its leader. APC however, cannot be empirically described as an ethnic militia because it was not armed; it did not represent a particular ethnic nationality and did not embark on any known anti-state or inter-ethnic violent action symbolic of ethnic militias before its disintegration on 26 February 2006 (Akinyele, 2001: 633). It was purely a pan-northern socio-cultural group. Later on, however, its ideals became subsumed under the Arewa Consultative Forum (ACF), a pro-Northern group that protects and projects the political interests of the entire northern part of Nigeria. In fact, in contradistinction with OPC, APF due to its varied composition lacked "the strong ethno-cultural base, appeal and cohesion of the OPC..." (Sesay, et al, 2003: 59).

Ethnic militancy, which found expression in OPC, was deployed by some Yoruba political elite as an instrument for the actualisation of their political objectives. Vociferous violence and agitations based on ethnicity aided the achievement of their political dream of clinching the civilian presidency for the first time in the political history of Nigeria. Although initially, they (the Yoruba political elite) generally expressed a high level of resentment and cynicism towards Obasanjo, soon after, he was warmly embraced, defended and supported by renowned Yoruba political elite, who felt pacified and compensated by the occupation of the hitherto elusive presidency by their son. Even the Adam's faction was made to come to terms with this reality, demobilised and toed the line of pacifism. Because primarily, these Yoruba elite have proved a point that: theirs is not an ethnic group that can be successfully marginalised on a prolonged basis in Nigeria's socio-economic cum political sphere, without dire consequences for the entire polity. The enormity of the impact was such that members of the Hausa/Fulani political elite had to literally sponsor and support the presidential bid of Obasanjo, in a concessionary move to placate the Yoruba for the annulment of the June 12 presidential election, the detention and death of Abiola in controversial circumstances.

\subsection{The Movement for the Actualisation of the Sovereign State of Biafra (MASSOB)}

MASSOB was established by Chief Ralph Uwazurike an Indian-trained Igbo lawyer on 13 September 1999, as an ethno-nationalist group fighting against the marginalisation of the Igbo ethnic nationality (or Ndigbo). It was established on the philosophical foundations of nonviolence, patterned after late Mahatma Ghandi, whose philosophy Uwazurike claimed to have studied for 10 years. In Uwazurike's words: "...The main issue that led to the formation of MASSOB is the marginalisation, discrimination, elimination, subjugation of Ndigbo in Nigeria" (cited in Onuoha, 2008: 24). Thus, MASSOB is an organisation that is basically concerned with the peaceful separation of the Igbo ethnic nationality from the Nigerian federation; it has a separatist agenda. Cognisant of the fact that the Nigerian military checkmated the original consolidation of the Biafran project, the termination of military rule and the subsequent inauguration of the $4^{\text {th }}$ republic created the long sought space for the formation of an ethno-nationalist organisation like MASSOB.

The agitation of the Igbos for a separate sovereign state distinct from Nigeria can be traced back to the deluge of political instability that occurred in the immediate post-independence era, which snowballed to the declaration of the Republic of Biafra by Lt. Col. Ojukwu on 30 May 1967 and, subsequently, the Nigerian civil war. The gory war, which claimed the lives of an estimated 3 million people, most of them Igbos, drastically altered the socio-economic and political standing of the Igbos in the Nigerian polity vis-à-vis the other two dominant groups. The war was decisively won by the Federal Military Government (FMG), which declared an unprecedented forgiveness for all Biafran belligerents. The reprieve was premised on the "no victor no vanquished" philosophical declaration of the Nigerian Head of state at the time, General Yakubu Gowon. This guaranteed the personal safety and security of lives and property of the Igbos after the civil war. Consequently, the government embarked on a policy of Reconstruction, Rehabilitation and Reconciliation (3 R's) aimed at the reintegration of the Igbos into the Nigerian polity (Obianyo, 2007; Onuoha, 2008).

Despite this seeming magnanimity and generosity of spirit, the Igbo perceived acts of marginalisation that were supposedly not in conformity with the public declarations of the FMG. The following examples should suffice:

* The promulgation, by the FMG, of the Banking Obligation (Eastern states) Decree of 1970, which ensured that all monies deposited in Banks by the Igbos between 30 May 1967 and 12 January 1970 were not 
recognised, and people were only paid 20 pounds each notwithstanding the amount of money involved. This was known as the ' 20 pound scandal'.

* The confiscation of landed property owned by Igbos, especially in Port Harcourt, and the subsequent institution of an Abandoned Properties Implementation Committee (APIC) by the FMG for the sale of those properties to the indigenes of Rivers state; who claimed to have captured them during the war.

* The deliberate implementation of the indigenisation policy from 1972, a period when the Igbos were not in a position to participate in the purchase of major shares in such companies.

- The refusal of the FMG to reabsorb Igbo military officers and civil servants back into the Nigeria military and the Federal Civil Service respectively (Ochonma, 2007; Obianyo, ibid).

These decisions, according to the Igbo political elite, were calculated policies aimed at their economic emasculation and strangulation and indicative of the vindictive disposition of the FMG despite its avowed public policy of 'no victor, no vanquished'. In furtherance of its operative exclusionary policies against the Igbos, it is contended that the FMG and the intermittent civilian administrations allegedly ensured that:

* No Igbo man becomes the executive president of post independent Nigeria, except late Aguiyi Ironsi whose administration was truncated by the Hausa/Fulani backed counter coup of 1966.

* Igbos are underrepresented in key positions at the federal level.

* Major federal institutions are not cited in Igboland.

- Igbos' are always singled out for premeditated killings at the slightest provocation, particularly in the northern part of Nigeria.

* The importation of foreign goods was banned to further emasculate the Igbos whose main occupation is commerce.

* Federal roads in the South-East geopolitical zone are neglected.

- The number of states in the South-East geopolitical zone is not increased to the same as that of other zones in Nigeria (Oha n'eze ndi Igbo, 1999; Ochonma, 2007; Obianyo, ibid). For example, whilst the South-East geopolitical zone has five states and 95 LGAs, the North-West geopolitical zone has seven states and 188 LGAs (Onuoha, 2009). Finally, is the grievance that is predicated on the perceived general disadvantageous socio-economic cum political positions hitherto occupied by the Igbos in comparison with the other two major ethnic nationalities in Nigeria.

It is against this backdrop that MASSOB was formed. Declaratively, MASSOB is a nonviolent organisation that is clamouring for the peaceful disintegration of Nigeria, in a manner similar to the collapse of the former Union of Soviet Socialist Republics (USSR). But operatively, MASSOB is a violent ethno-national group because it has sought to impose its authority in the mobilisation and compelling of Igbos in Nigeria to compulsorily observe the annual sit-at-home order in support of the ideals of the movement, the distribution of Biafran currency and encouragement of people to adopt it as a legal tender, compelling people to observe sanitation laws, the establishment of military camps, paramilitary training of its members, sewing of Biafran military uniforms and the circulation of Biafran souvenirs such as stickers, umbrellas, belts and almanacs.

From the above, it is clear that despite MASSOB's principle of nonviolence, it has been involved in armed militancy through the use of intimidating tactics, outright force and violence in coercing people to behave in accordance to its instructions. Thus, notwithstanding its pacifist declarations, MASSOB has apparently been using violence as a strategic instrument for the realisation of its set objectives; hence its categorisation as an ethnic militia. Secondly, MASSOB's assertion of sovereignty over a geopolitical sphere and people that legally and internationally belong to the Nigerian state and its use of violence placed it on a collision course with the Nigerian state and provoked a backlash of security actions geared towards checkmating its activities in the South-East geopolitical zone.

Furthermore, though MASSOB is popular amongst youths, artisans, traders, unemployed, commercial cyclists and drivers, the established political elite and members of the pan-Igbo socio-cultural group, the Ohan'eze Ndi Igbo, view its activities as treasonable felony and an undue distraction from their peaceful fight against the marginalisation of the Igbos. Therefore, while the Igbo political elite are in total agreement with the fact that the Igbo ethnic nationality is being marginalised in the Nigerian polity, they disagree with the modus operandi of MASSOB. It was in consonance with this reality that the governor of Anambra state, Mr. Peter Obi, of the All Progressive Grand Alliance (APGA) political party asked for the deployment of soldiers to battle and flush out the insurgent MASSOB from the state in 2006.

Therefore, unlike OPC, MASSOB cannot be described as a ethnic militant group deployed by members of the Igbo political elite for the realisation of its collective political objectives. Against this backdrop, it defies the elite-instrumentalist perspective of ethno-nationalist rationalisation. The overt disagreement between Igbo political elite and MASSOB is a testimony to this fact. In fact, it has been argued that the emergence of ethnic militancy, which found expression in MASSOB in the South-East, is indicative of the materialisation of "an alternative project to the elite-based politics in Igboland" (Onuoha, 2009: 38). Apparently, this is distinct from 
the seemingly conservative and opportunistic political class in the ethnic group. It is also symptomatic of revolutionary pressures in Igboland in particular and Nigeria in general.

Finally, despite the blanket criminalisation of the movement by the Nigerian state and some members of the political elite from the South-East geopolitical zone, MASSOB's grievance of marginalisation against the Igbo ethnic nationality in the Nigerian socio-economic and political space are genuine and require urgent redress. Thus like OPC, the formation of MASSOB can be rightly described as grievance-driven.

\subsection{The Movement for the Emancipation of the Niger Delta (MEND)}

Apart from the struggle for self-determination, environmental remediation and resource control, two major factors account for the formation of a more armed, better organised, more vocal and more sophisticated ethnic militia known as the Movement for the Emancipation of the Niger Delta (MEND). The first was the arrest, impeachment, re-arrest, detention and trial of Alamieyeseigha, a former governor of Bayelsa, the only Ijaw state, on the charges of corruption and money laundering. It believed that Alamieyeseigha may have been targeted because of his principled stance on resource control. Therefore, his trial was viewed by Ijaws as selective, vindictive and an act of political persecution by Obasanjo (Ebiri, 2007).

The second factor was the arrest, detention and trial of Asari Dokubo in 2005 despite the federal government-driven 2004 peace accord. Various militias from the Ijaw ethnic nationality went underground, because it was reasoned that his arrest signalled government's crackdown on the Ijaws and its gross insincerity to the terms of the October 2004 amnesty. The Obasanjo government was also accused of preferential treatment for the 'safe passage' his administration granted members of his ethnic nationality that were allegedly arrested for similar offences. Relevant examples are Dr. Fasheun and Gani Adams of the OPC fame (Gbemudu, 2006; Ebiri, 2007).

Consequently, towards the end of 2005, Tompolo convened a meeting of prominent Ijaw militants, basically from FNDIC and NDPVF, at Okerenkoko to re-strategise the Ijaw armed struggle for selfdetermination and resource control, which as a minimum requirement must include the release of both Alamieyeseigha and Dokubo. MEND was therefore created in late 2005 with Henry Okah, a notable arms dealer resident in South Africa as the spokesperson - e-mailer (cited in Sahara Reporters, 2007). MEND came to limelight on 11 January 2006 when it launched an attack on Shell's Brass Creek manifold pipeline in Bayelsa state and kidnapped four foreign workers with Tidex Nigeria Limited, an oil servicing firm working for Shell (SNEPCO) the same day (Davies, 2009). MEND claimed responsibility for the attacks and demanded the payment of $\$ 1.5$ billion as compensation to Bayelsa state for accumulated years of environmental degradation and despoliation, resource control, the vacation of Shell from the Delta region and the unconditional release of Dokubo and Alamieyeseigha. The four expatriates were allegedly spirited to Tompolo's camp at Okerenkoko, where they were kept until their release on 30 January after the payment of an undisclosed amount of ransom by the Bayelsa state government to MEND (Asuni, 2009: 17-18).

Consequently, MEND focused on the kidnapping of expatriate oil workers from North America and Western Europe as one of its strategies of attracting foreign attention to the Niger Delta situation, and mounting pressure on both the Nigerian state and the Multinational oil companies (MNOCs). Clearly, the use of these strategies further elevated and sustained the Niger Delta struggle on both national and international discourse. It's short-term strategic objective was to cripple Nigeria's ability to produce and export oil from the Niger Delta by systematically destroying the petroleum infrastructure and kidnapping of expatriates working for the MNOCs, if its demands were not met. The strategy was not particularly meant to annihilate the oil sector, but to use it for the attainment of its socio-economic cum political objectives.

The enormity of the destruction inflicted on the infrastructure of the MNOCs and the Nigerian economy by MEND was undoubtedly colossal and unprecedented. For example, by the end of June 2006, the Nigerian economy had lost over \$2.18 billion in revenue (Watts, 2007: 647); Shell had shut down its operations in Delta state and declared force majeure due to the deferment of about 600,000 bpd (Davies, 2009: 81). Furthermore, the Managing Director of Shell stated that Nigeria lost about $\$ 9$ billion in oil revenue between January and November 2006 (Watts, 2007). However, the Technical Committee on the Niger Delta (TCND) reported that \$29.1 billion, \$18.8 billion and \$23.7 billion were the estimated oil revenue losses in 2006, 2007 and 2008 respectively. And by the end of May 2009, Nigeria's oil production capacity had dwindled from 2.4 million bpd to about 1.2 million bpd due largely to militancy championed by MEND .

Unlike OPC and MASSOB, MEND was an amorphous group without identifiable leadership arrangement. It also collaborated with several other ethnic militias, gangs and some 'volunteer militants' in the Delta region for the actualisation of its goals and objectives. Although it was basically formed as an Ijaw belligerent ethno-nationalistic group, MEND gradually evolved as an organisation championing the cause of the totality of the marginalised Niger Deltans, thereby "placing its struggle in a social rather than ethnic context" (Briggs, 2007: http://www.jamestown.org/single/?; accessed 30/08/2007). 
Further, the arrest of Henry Okah in September 2007 and the intensification of military campaign by the Nigerian state against MEND positions in Delta State on 13 and 14 May 2009 exacerbated the belligerency of the organisation and attracted more sympathisers and supporters from the Niger Delta to its cause. The unconditional release of Okah was one of the demands of MEND until a general amnesty was declared for all militants involved in militancy in the Niger Delta on 25 June 2009 by the Nigerian state. The amnesty provided a window of opportunity for several MEND militants to renounce violence, surrender their arms and become 'free citizens' of the Federal Republic of Nigeria again. Some of them are: Victor Ben Ebikabowei alias General Boyloaf, Henry Okah, Fara Dagogo, Government Ekpemupolo (aka Tompolo or GOC), late Soboma George and Biibo Ajube. Consequently, there was significant de-escalation of conflict in the Niger Delta; construction firms and MNOCs returned to their usual business of infrastructural building and oil production respectively.

Similar to OPC and MASSOB, the formation of MEND can be rightly described as grievance-driven. However, unlike OPC, MEND was not specifically formed according to the framework of elite-instrumentalist theoretical perspective - it was not established by Ijaw political elite for the purpose of the realization of specific political objectives. It is worthy of note however, that due to its amorphous nature, some members of the political elite at various times deployed a number of supposed MEND members for personal political gains. Lastly, the fact that MEND championed the cause of resource control, coupled with the heavy-handed militaristic approach adopted by the Nigerian state, prompted several Ijaw and other Niger Delta political elite to sympathise, support and identify with the goals and travails of the militia group.

\section{Concluding Remarks and the Way Forward}

The elaborate and comparative reappraisal of these three ethno-nationalist groups, OPC, MASSOB and MEND reveals that their establishment was predicated on legitimate grievance-related issues. They were founded for the articulation, prosecution and actualisation of the political and socio-economic goals of their respective ethnic group/region. Thus, ethnic militancy was deployed for the enhancement of the fortunes of their respective ethnic nationalities. However, OPC is the only ethnic militia that fits into the classical eliteinstrumentalist theoretical perspective; an ethno-nationalist organisation purposefully established by members of the political elite for the achievement of their (ethnic) political objectives. It cannot be categorically stated that the other two groups (MASSOB and MEND) were deliberately established by members of the political elite for the purpose of attaining the political goals of their respective ethnic nationalities. The support given to them by both the political elite and the generality of their respective ethnic groups further gives the impression that they were also formed by the political elite for the realisation of ethnic goals at the national level. But research proves that this is hardly true. However, as we have attempted to prove, some members of the political elite used some of the militias as instruments of personal political aggrandisement and this was a particularly worrisome feature of MEND.

In addition, two out of the three militia groups (OPC and MEND) called for the convocation of a Sovereign National Conference to discuss the possibility of restructuring the Nigerian polity. MASSOB on the other hand, is the only group with a separatist agenda; that calls for the outright but peaceful dissolution of the political entity known as Nigeria. Clearly, this is a pointer to the need for an urgent networking and collaboration by political elite in the country; for the purpose of devising a holistic approach for the resolution of the multiplicity of challenges bedevilling the Nigerian polity. And of course, a Sovereign National Conference or an inclusive national conference whose decisions will be ratified only by an appropriately conducted referendum is currently, an obvious fundamental means through which the legitimate grievances of Nigerians can be realistically addressed. If the convocation of a Sovereign National Conference is unacceptable to the incumbent government due to palpable threats to the status quo, then she should convene a national dialogue made up of the legitimate representatives of the various identifiable ethnic nationalities in Nigeria, representatives of the constitutionally recognised interest groups (civil society organisations) and perhaps, some appointed representatives of the incumbent government to discuss extensively and reasonably the myriad problems confronting Nigeria since independence with a view to amicably arriving at practicable solutions.

\section{References}

[1]. Ake, C. (1996). "The Political Question" in: Oyediran, O. (eds.), Governance and Development in Nigeria: Essays in Honour of Billy J Dudley. Ibadan: Oyediran Consult International.

[2]. Akinboye, S. O. (2001). "The Matrix of Ethnicity and Ethno-Religious Crises in Nigeria's Nascent Democracy" in: Eruvbetine, A. E. (eds.), The Humanistic Management of Pluralism. Lagos: Faculty of Arts, University of Lagos.

[3]. Akinyele, R.T. (2001). "Ethnic Militancy and National Stability in Nigeria: A Case Study of The Oodua People's Congress." African Affairs, Vol. 100, No.401, pp. 623-640. ---

[4]. Anifowose, R. (2000). Urban Violence in Nigeria: The Case of the Oodua Peoples' Congress (OPC) Militia. Being a Paper Presented at the Faculty of Social Science Conference on "Industrialisation, Urbanisation and Development in Nigeria, 1950-1999 and Beyond". University of Lagos, 15 and 16 November.

[5]. Asuni, J. B. (2009). Blood Oil in the Niger Delta. Special Report. Washington DC: United States Institute of Peace. 
[6]. Auster, A. (1996). "Review of Human Rights Watch 'Slaughter among Neighbours: The Political Origins of Communal Violence." Journal of International Affairs, Vol. 50, No. 1, pp. 314-338.

[7]. Awodiya, M. (2006). "The Challenge of Ethnic Nationalism." Vanguard, 25 January. Available at: www.vanguardngr.com. Accessed 29/02/2007.

[8]. Babawale, T. (2001). "The Rise of Ethnic Militias, Delegitimisation of the State and Threat to Nigeria Federalism," West Africa Review, Vol. 3, No. 1, pp. 1-12.

[9]. Briggs, J. (2007). "Guide to the Armed Groups Operating in the Niger Delta - Part 2." Terrorism Monitor, Vol. 5 , Issue 7. Available at: http://www.jamestown.org/single/? Accessed 30/08/2007.

[10]. Coleman, J. S. (1971). Nigeria: Background to Nationalism. Berkeley and Los Angeles, CA: University of California Press.

[11]. Diamond, L. (1988). "Ethnicity and Ethnic Conflict." Journal of Modern African Studies, Vol. 25, No. 1, pp. 117-128.

[12]. Ebiri, K. (2007), "Rivers: A Long List of Kidnappings." The Guardian, 23 September.

[13]. Enloe, C. H. (1980). Police, Military and Ethnicity: Foundations of State Power. New Brunswick, NJ: Transaction Books.

[14]. Eriten, N.D and Romine, J. (n.d.). "Instrumental and Symbolic Sources of Ethnic Conflict: Application to the Kurdish Conflict in Turkey."

[15]. Fasehun, F.I. (2002). Frederick Fasehun, the Son of Oodua. Lagos: Inspired Communication.

[16]. Gbemudu, E. (2007). "Bayelsa's Dairy of Hostage-Taking in 2006.” Daily Independent. 2 January.

[17]. Gilbert, L.D (2010). Ethnic Militias and Conflict in the Niger Delta Region of Nigeria: The International Dimensions (1999-2009). Doctoral Thesis Submitted to University of KwaZulu-Natal, Howard College Campus, South Africa.

[18]. Guichaoua, Y. (2006). The Making of an Ethnic Militia: The Oodua People's Congress in Nigeria. Crise Working Paper No. 26. Oxford: Centre for Research on Inequality, Human Security and Ethnicity, CRISE Queen Elizabeth House.

[19] Jinadu, A. L. (1985). "Federalism, the Consociational State, and Ethnic Conflict in Nigeria." Publius: The Journal of Federalism, Vol. 15, No. 2, pp. 71-100.

[20]. Metumara, D. M. (2010). “Democracy and the Challenge of Ethno-Nationalism in Nigeria's Fourth Republic: Interrogating Institutional Mechanics.” Journal of Peace, Conflict and Development, Issue 15, pp. 92-106.

[21]. Nnoli, O. (ed.) (1993). Dead-End to Nigerian Development: An Investigation on the Social Economic and Political Crisis in Nigeria. Dakar: CODESRIA Book Series.

[22]. Osaghae, E. E. (2001). "From Accommodation to Self-Determination: Minority Nationalism and the Restructuring of the Nigerian State." Nationalism and Ethnic Politics, Vol. 7, No.1, pp. 1-20.

[23]. Osaghae, E. E. (1995). Structural Adjustment and Ethnicity in Nigeria. Uppsala: Nordic African Institute.

[24]. Osaghae, E. (1991). "A Re-Examination of the Conception of Ethnicity in Africa as an Ideology of Inter-Elite Competition." African Study Monographs, Vol. 12, No. 1, pp. 43-60.

[25]. Otite, O. (1975). "Resource Competition and Inter-Ethnic Relations in Nigeria" in: Despres, L. A. (eds.), Ethnicity and Resource Competition in Plural Societies. The Hague: Mouton Publishers.

[26]. Reno, W. (2006). "Insurgencies in the Shadow of State Collapse" in: Kaarsholm, P. (eds.) Violence, Political Culture and Development in Africa, Oxford: James Currey Ltd

[27]. Report of the Technical Committee on the Niger Delta. (2008). Retrieved from http://www.mosop.org/Nigeria Niger Delta Technical Committee Report 2008.pdf

[28]. Sesay, A., Ukeje, C., Aina, O., and Ōdebiyi, O. (eds.) (2003). Ethnic Militias and the Future of Democracy in Nigeria. Ile-Ife: Obafemi Awolowo University Press.

[29]. Ukeje, C. and Adebanwi, W. (2008). "Ethno-Nationalist Claims in Southern Nigeria: Insights from Yoruba and Ijaw Nationalisms since the 1990s." Ethnic and Racial Studies, Vol. 31, No. 3, pp. 563-591.

[30]. Watts, M. (2007). "Petro-Insurgency or Criminal Syndicate? Conflict and Violence in the Niger Delta." Review of African Political Economy, Vol. 34, No. 114, pp. 637-660.

[31]. Young, C. (1994). "Evolving Modes of Consciousness and Ideology: Nationalism and Ethnicity" in: Apter, D. and Rosberg, C. (eds.), Political Development and the NewRealism in Saharan Africa. Charlottesville: University Press of Virginia. 